\title{
NITRIFICATION DYNAMICS UNDER SUBMERGED AND AERATED SOIL CONDITIONS
}

\author{
Shahzad H., lqbal M. \\ Institute of Soil \& Environmental Sciences, University of Agriculture \\ Faisalabad, Pakistan \\ E-mail: rhs2140@ymail.com
}

\begin{abstract}
Nitrogen is a pivotal component of proteins making $60 \%$ dry matter of plant cell. It is reported deficient in most of the soils of world. An incubation study was conducted to assess $\mathrm{N}$ transformations under aerobic and submerged conditions using organic amendment. Maximum oxidation of $\mathrm{NH}_{4}$ was observed in organically amended soils followed by control treatment. Nitrification is $\mathrm{NH}_{4}$ to $\mathrm{NO}_{3}$ conversion process was observed to be lowest under submerged condition. With passage of incubation time $\mathrm{NO}_{3}$ content in organically amended and control treatment get enhanced while under flooded conditions least declining trend in $\mathrm{NH}_{4}$ content was observed from start to ending days. Least $\mathrm{N}$ losses were observed in organically amended aerated soil.
\end{abstract}

\section{KEY WORDS}

Aerated, aerobic, nitrification, mineralization, submerged.

Food security is most discussable issue these days because of increasing population. To meet the needs of population agriculture production has to be enhanced utilizing same piece of land. The success story of arable forming without $\mathrm{N}$ fertilizer seems impossible because $\mathrm{N}$ is deficient in majority of soils. Fertilization aims optimized crop yield and quality that can give high economic returns for the investment. Nitrogen is considered most important nutrient with least uptake efficacy because nitrogenous fertilizers are subjected to various reactions, transformations and nitrogen loss mechanisms i.e. $\mathrm{NH}_{3}$ volatilization [(Sluan and Audesson,1995)] nitrification, denitrification [(Rolston and Broadbent, 1977)], leaching [(wild and cameron, 1980 ; Nielson 1982)], immobilization [(Shimpi and Savant, 1975)] and runoff [(Takamua et al., 1977)]. So major proportion of applied $N$ is lost by these processes [(Smith and Whitfield, 1990; shah et al., 1993)]. Efficacy of $\mathrm{N}$ is very almost $50 \%$ for upland grain crops [(Roy and Chandra, 1979)] but only $30-45 \%$ for lowland rice [(Vlelk and craswell, 1981; Zia \& Waving, 1987)].

Major objective of today agriculture is to get more economic yield with least cost that can only be achieved through enhancing nutrient use efficiency. Major $\mathrm{N}$ application for optimum crop growth all over the world is in the form of urea that upon hydrolysis increases soil pH causing tremendous losses in the form of ammonia volatilization [(Fan et al., 1993; Hamid et al., 1998)]. Redox reactions resulting from alternate flooding and drying cycle also causes $\mathrm{N}$ losses by nitrification and denitrification [(Burferd and Bremnar, 1975)]. Fertilizer management practices can be one way to reduce $\mathrm{N}$ losses [(Rao et al., 1987; Fiez et al., 1995; Saad et al., 1996)]. These practices are fruitful when someone understand the transformation procedure [(Saad et al., 1996)]. Present study was, therefore, envisaged to understand $\mathrm{N}$ transformation under aerobic \& flooded condition.

\section{Materials and Methods}

A controlled field study was conducted to evaluate the $\mathrm{N}$ transformations under aerated and submerged condition using organic amendment. Following treatment plan was used:

$$
\begin{gathered}
\text { T0 = control }[(\text { aerobic })] \\
\text { T1 = Aerobic }+ \text { Organic liquid } \\
\text { T2 = Flooded } / \text { Submerged }
\end{gathered}
$$

Cores were inserted in soil so as not to disturb the soil natural environment at field 
research area Institute of Soil and Environmental Sciences, University of Agriculture Faisalabad, Pakistan.

Physicochemical characteristics of soil before study are given in Table 1.

Table1 - physicochemical analysis of soil used in study

\begin{tabular}{|c|c|c|}
\hline Parameter & Units & Value \\
\hline Sand & $\%$ & 40 \\
\hline Silt & $\%$ & 37.5 \\
\hline Clay & $\%$ & 22.5 \\
\hline texture clam & & Loam \\
\hline $\mathrm{pH}$ & $\mathrm{Mg} \mathrm{m}^{-3}$ & 8.2 \\
\hline Bulk density & $\mathrm{dS} \mathrm{m}^{-1}$ & 1.52 \\
\hline EC & $\%$ & 1.45 \\
\hline Total carbon & $\%$ & 0.5 \\
\hline Total N & $\%$ & 0.03 \\
\hline $\mathrm{K}$ & $\mathrm{mg} \mathrm{kg}^{-1}$ & 112 \\
\hline $\mathrm{P}$ & $\mathrm{mg} \mathrm{kg}^{-1}$ & 8 \\
\hline
\end{tabular}

Moisture content was maintained at $75 \%$ of WHC in control and organically amended treatments by addition of DI water and organic liquid, respectively. In $T_{2}$ soil was flooded by DI water. Each treatment was replicated 18 times. Three cores were sacrificed each time for analysis of $\mathrm{NH}_{4}$ and $\mathrm{NO}_{3}$ as samples after $0,1,2,4,7,11$ and 15 days of starting study.

$50 \mathrm{~mL} 1 \mathrm{~N} \mathrm{KCl}$ solution added to $20 \mathrm{~g}$ soil in a plastic bottle and mixed by shaking on reciprocating shaker. Then it was filtered using Whatman No. 42 filter paper. Kjeldahl method was used for $\mathrm{NH}_{4}$ and $\mathrm{NO}_{3}$ analysis [(Keeney and Nelson, 1982)].

\section{RESULTS OF RESEARCH}

Studies account for nitrogen transformation under various soil conditions have given divergent results and various explanations have been advanced for each effect.

Amonical $\mathrm{N}$ in soil $\left[\left(\mathrm{NH}_{4}-\mathrm{N}\right)\right]$ : $\mathrm{NH}_{4}$ concentration under different treatment dropped significantly with passing days. Maximum reduction was observed in control aerated followed by organically amended and submerged treatments as evident from (fig. 1).

Less amount of $\mathrm{NH}_{4}-\mathrm{N}$ in control is due to its nitrification while elimination of air from pores by water create reduced condition that inhibit nitrification [(Vlek and Craswell, 1981)]. [Saffinga et al., (1982)] have presented the same concluding remarks. In organically amended soil amount of $\mathrm{NH}_{4}$ was higher that was supposed to be due to sheltering of $\mathrm{NH}_{4}$ ion to the negative site of organic matter leaving least amount prone to nitrification. After 11 days $\mathrm{NH}_{4}$ content increased again due to mineralization of organic pool and stimulatory effect of $\mathrm{NH}_{4}$ ion on nitrification prior to hydrolysis reduced $\mathrm{NH}_{3}$ volatilization [(Hamid et al., 1998)].

Nitrate Nitrogen $\left[\left(\mathrm{NO}_{3}-\mathrm{N}\right)\right]$ in Soil: Concentration of $\mathrm{NO}_{3}-\mathrm{N}$ enhanced gradually in the whole run described in (Fig. 2). Maximum increment was observed in organically amended treatment followed by control and submerged soil. In start control produced more $\mathrm{NO}_{3}$ upto 2 days as more $\mathrm{NH}_{4}$ was prior to nitrification than other two treatments. In starting days $\mathrm{NH}_{4}$ was bound to negative charge bearing sites of organic material but later on due to mineralization of organic matter $\mathrm{NH}_{4}$ released and oxidized to form $\mathrm{NO}_{3}$. Nitrification of $\mathrm{NH}_{4}$ to $\mathrm{NO}_{3}$ was lowest under submerged conditions due to lower oxygen in soil. These results matches with [(Wild and Cameson, 1980; Magalhaes and Chalk, 1987; Saad et al., 1996)].

Mineral $\mathrm{N}$ and losses: Mineral $\mathrm{N}\left(\mathrm{NH}_{4}+\mathrm{NO}_{3}-\mathrm{N}\right)$ under control and organically amended treatment increased with incubation time (Fig-3) adopting almost same increasing trend in both treatments. While declining trend was observed for submerged conditions. For both aerated treatments decline was observed for the very first day but a sharp increase after that because of mineralization of organic matter under aerobic condition. Mineral $\mathrm{N}$ content was declined continuously from day 0 to end of the term that is attributed to denitrification of nitrate by microbes and oxygen was not present for $\mathrm{NH}_{4}$ oxidation or organic matter decomposition. These results are fulfilling the concluding lines of [(Saffigna et al., 1982; Magahaes and Chalk, 1987)]. 


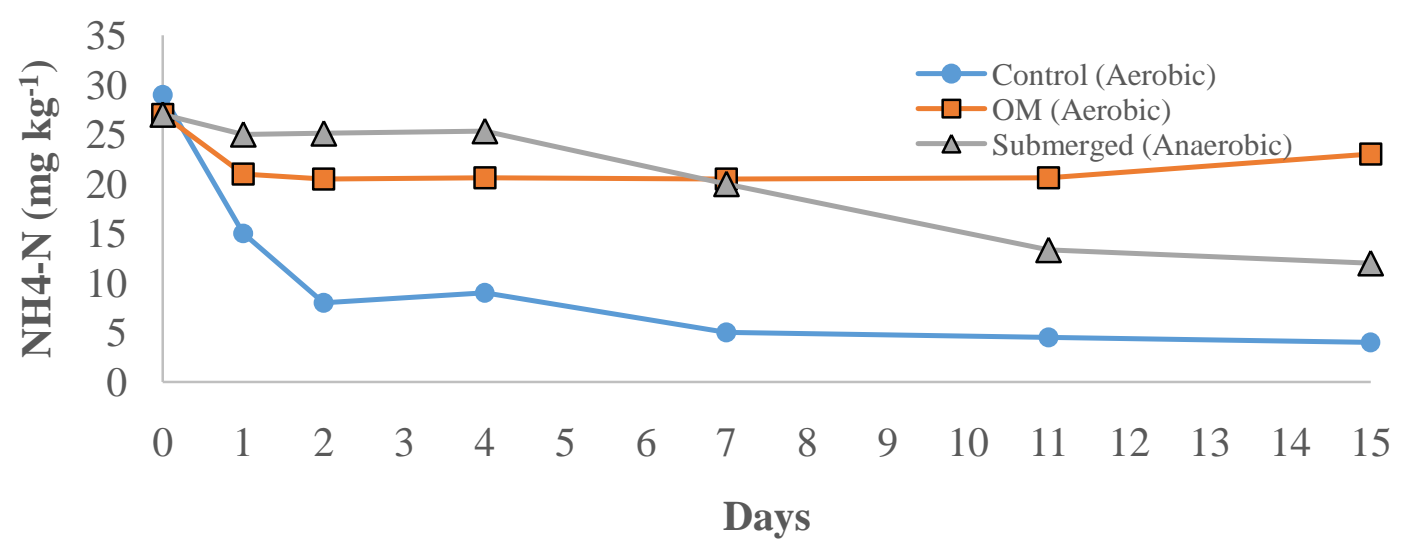

Figure 1 - Ammonium dynamics in soil under aerobic and anaerobic enviroments

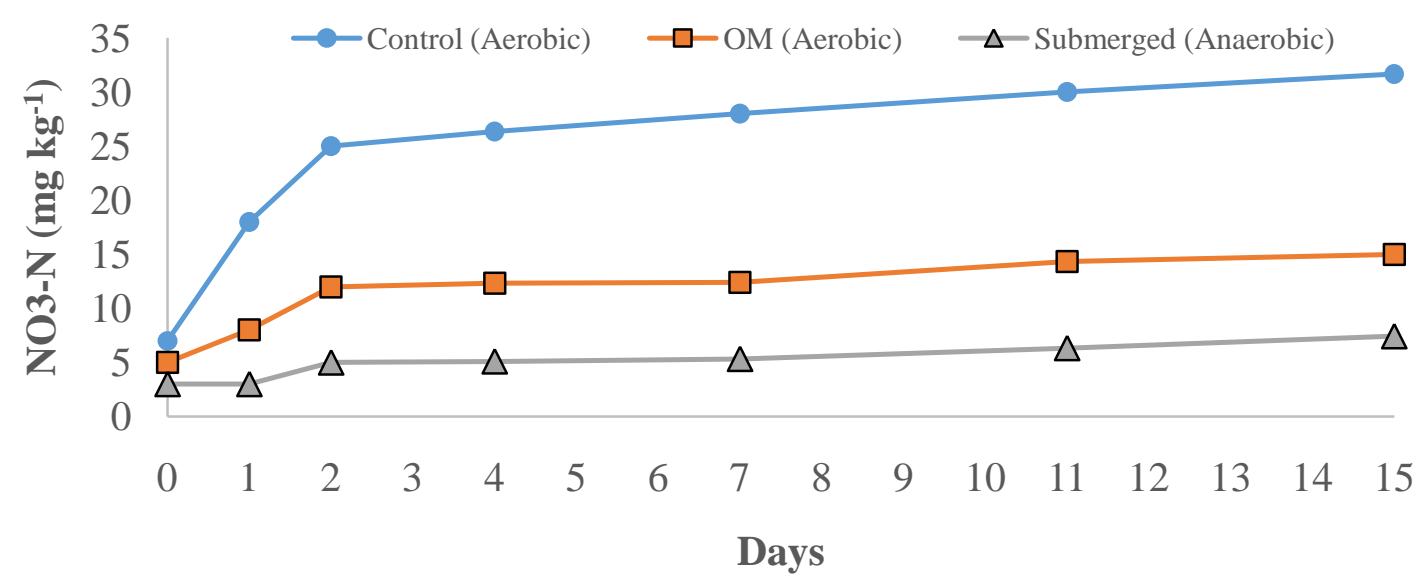

Figure 2 - Nitrate dynamics in soil under aerobic and anaerobic enviroments

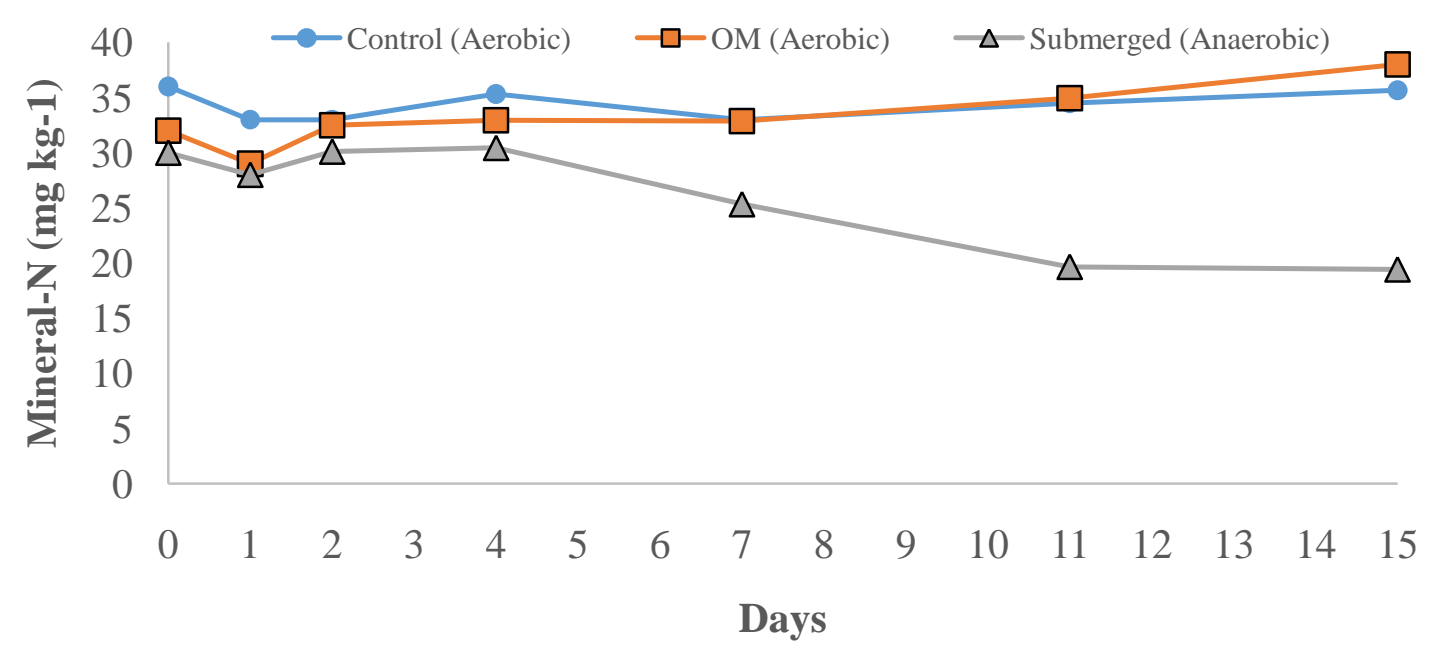

Figure 3 - Mineral $\mathrm{N}$ dynamics in soil under aerobic and anaerobic enviroments 


\section{CONCLUSION}

From this study it is concluded that under submerged conditions major loss of nitrogen is due to denitrification process. Such type of losses can be reduced by creating aerobic environment through better soil management practices.

\section{ACKNOWLEDGEMENTS}

We are thankful to Higher Education Commission of Pakistan for funding to conduct this research. We are also thankful to Mr. Muhammad Imran for his guidance in planning while Mr. Noman Ali, Muhammad Sabir and Abubakar Siddique for writing this research.

\section{REFERENCES}

1. Burford, J.R. and J.M. Bremner. 1975. Relationship between denitrification capacities of soils and total water soluble and readily decomposable soil organic matter. Soil Biol. Biochem. 7:389-94.

2. Craswell, E.T. and P.L.G. Vlek. 1979. Greenhouse evaluation of nitrogen fertilizer for rice. Soil Sci. Soc. Am. J., 43:1184-8

3. Fan. M.X. and A.F. Mackenzie. 1993. Urea and phosphate interactions in fertilizer microsites: Ammonia volatilization and pH changes. Soil. Sci. Soc. Am. J. 57: 839-45.

4. Fiez, T.E., W.L. Pan and B.C. Miller. 1995. Nitrogen use efficiency of winter wheat among landscape position. Soil Sci. Soc. Am. J., 59: 1666-71.

5. Hamid A., M. Ahmad and M. Yaqub. 1998. Behavior of nitrogen fertilizer in alkaline calcareous soils. Pakistan J. Soil Sci., 15: 56-61.

6. Keeney, D.R. and D.W. Nelson. 1982. Nitrogen inorganic forms. P. 594-624. In: Methods of soil analysis. Page, A.L., R.H. Miller and D.R. Keeney [(eds)]. American Soc. Agron. Madison, Wisconsin.

7. Magalhaes, A.M.T. and P.M. Chalk. 1987. Nitrogen transformation during hydrolysis and nitrification of urea. II. Effect of fertilizer concentrations and nitrification inhibitors. Fert. Res., 11: 173-84.

8. Nielson, D.W. 1982. Gaseous losses of nitrogen other than through denitrification. In: F.G. Stevenson [(ED.)], Nitrogen in Agricultural Soils. Agronomy Monograph No. 22, Madison Wisconsin: American Son.

9. Rao, D.L.N. 1987. Slow release urea fertilizer effect on floodwater chemistry, ammonia volatilization and rice grow in alkali. soil Fert. Res.13: 209-21.

10. Rolston, D.E. and F.E. Broadbent. 1977. Field measurement of denitrification. EPA 600/277-33. Ada Oklahoma, US Environmental Protection Agency.

11. Roy, R.N. and S. Chandra. 1979. Increasing the efficiency of fertilizer use in India. Fertilizer Industry: 17-27.

12. Saad, O.A.L.O., S. Lehmann and R. Conrad. 1996. Influence of thiosulfate on nitrification denitrification and production of nitric oxide and nitrous oxide in soil. Biol. Fertil. Soil. 21: 152-9.

13. Saffigna, P.G., A.L. Cogle, W.M. Strong and S.A. Waring. 1982. The effect of carbonaceous residues on $\mathrm{n}$ fertilizer nitrogen transformation in the field. In: Frency, J.R. and F.E. Galbally [(Eds)], cycling carbon, nitrogen, sulphur and phosphorus in terrestrial and aquatic ecosystem, pp: 83-90. Springer Verlag, Berlin Weeidelhers of New York.

14. Shah, Z., J.K. Khattak, and R. Ali. 1993. Fate of applied nitrogen in soil plant system and its effect on yield of maize [(Zea mays L.)]. Sarhad.J. Agri. 9: 435-55.

15. Shimpi, S.S. and N.K. Savant. 1995. Ammonia retention in tropical soils as influenced by moisture contents and continuous submergence. Soil Sci. Soc. Am. Proc. 39: 153-4.

16. Sloan, J.J. and W.B. Anderson. 1995. Calcium chloride and ammonium thiosulphate as ammonia volatilization inhibitors for urea fertilizer. Commun. Soil Sci. Plant Anal. 26: 2425-47. 
17. Smith, C.J. and D.M. Whitfield. 1990. Nitrogen accumulation and redistribution of late application of $15 \mathrm{~N}$ labeled by wheat. Field Crop Res. 24: 211-26.

18. Takamura, Y., T. Tabuchi and H. Kubota. 1977. Behavior and balance of applied nitrogen and phosphorus under applied field conditions, pp: 342-49. In: Proc. Intl. Sem. Soil Environ. Fert. Manag. Intensive Agri. [(SEFMIA)], Tokyo-Japan. Society of the Science of Soil and Manure, Japan.

19. Vlek, P.L.G. and E.T. Craswell. 1981. Ammonia volatilization from flooded soils. Fert. Res. 2: 227-45.

20. Wild, A. and K.C. Cameron. 1980. Soil nitrogen and nitrate leaching. In: P.B. Tinker [(Ed)], Soil and Agriculture, pp: 35-70, Society of Chemistry Industry. Critical Report on Applied Chemistry, Vol. 2, Oxford Blackwell Scientific.

21. Zia, M.S. and S.A. Waving. 1987. Balance sheet of $\mathrm{N}$ labeled urea applied to rice in three Australian Vertisols differing in soil organic carbon. Fert. Res. 12: 53-65. 